\title{
Vegetative growth of citrus nursery trees related to the container volume
}

Eduardo Augusto GIRARDIa ${ }^{a}$, Francisco de Assis Alves Mourão FILHO ${ }^{a \star}$, Christiano César Dibbern GrAF $^{b}$, Fernando Bacic OLIC ${ }^{a}$

a Dep. Produção Vegetal, USP/ ESALQ, CP 9, Piracicaba, SP, 13418-900, Brazil

famourao@esalq.usp.br

b Citrograf Mudas, Rodovia SP 191, Km 21.4, 13835-970,

Conchal, SP, Brazil
${ }^{*}$ Correspondence and reprints

Received 23 April 2004 Accepted 14 January 2005

Fruits, 2005, vol. 60, p. 101-105 (C) 2005 Cirad/EDP Sciences All rights reserved

DOI: $10.1051 /$ fruits:2005020

RESUMEN EsPañol, p. 105

\section{Vegetative growth of citrus nursery trees related to the container volume.}

Abstract - Introduction. The determination of an adequate container volume that combines rational use of substrate with maximization of vegetative growth is very important to optimize citrus nursery tree production. This experiment aims to evaluate the influence of container volumes on vegetative growth of citrus nursery trees. Materials and Methods. Pera sweet orange nursery trees [Citrus sinensis (L.) Osbeck] budded on Rangpur lime (Citrus limonia Osbeck) were produced in six container volumes $[(3.0,3.8,4.5,4.6,5.0$ and 5.8$) \mathrm{L}]$, with the respective container dimensions of $[(20 \times 32,20 \times 35,22 \times 32,22.5 \times 35,25 \times 32$ and $25 \times 35) \mathrm{cm}]$. Another 5.0-L container studied had the dimensions of $20 \mathrm{~cm} \mathrm{x} 40 \mathrm{~cm}$. Commercial substrate was composed of Pinus bark and a controlled-release fertilizer was used. Parameter evaluation started after moving the rootstocks from seedling trays, 3.5 months after sowing, to plastic containers and continued until nursery trees reached one year old. The studied parameters were shoot height, diameter and leaf area of rootstocks and nursery trees, bud take percentage and scion and root dry matter of nursery trees. Results and discussion. The development of Rangpur lime plants was not affected by any treatment until budding. The largest container volumes induced faster and more vigorous vegetative development of Pera sweet orange nursery trees budded on Rangpur lime. A 5.0-L container volume could be indicated as a technical and economical option for the production of containerized citrus nursery trees.

Brazil / Citrus sinensis / Citrus limonia / plant propagation / plant nurseries / container planting / growth / measurement

\section{Croissance végétative des arbres en pépinière d'agrumes en rapport avec le} volume du container.

Résumé - Introduction. La détermination d'un volume de container adéquat qui combine une utilisation rationnelle du substrat et une croissance végétative optimale est très importante pour optimiser la production d'arbres en pépinière d'agrumes. Cette expérimentation a visé à évaluer l'influence des volumes de containers sur la croissance végétative d'agrumes en pépinière. Matériel et méthodes. Des orangers de la variété Pera [Citrus sinensis (L.) Osbeck] greffés sur limettier Rangpur (Citrus limonia Osbeck) ont été plantés dans des containers de six volumes différents $[(3,0 ; 3,8 ; 4,5 ; 4 ; 6 ; 5,0$ et 5,8) L ], correspondant à des dimensions respectives de $(20 \times 32,20 \times 35,22 \times 32,22.5 \times 35,25 \times 32$ et $25 \times 35) \mathrm{cm}$. Un autre container de $5,0 \mathrm{~L}$ et $20 \mathrm{~cm} \times 40 \mathrm{~cm}$ a été testé. Le substrat commercial était constitué d'écorce de pin et un engrais à libération contrôlée a été utilisé. Les mesures ont commencé après transfert, 3,5 mois après le semis, des porte-greffes issus de plantules en planches dans des containers de plastique et elles ont été poursuivies jusqu'à ce que les arbres de pépinière aient atteint l'âge d'un an. Les paramètres étudiés ont été la hauteur de tige, le diamètre et la surface des feuilles des portegreffes et des arbres de pépinière, le pourcentage de reprise et de la matière sèche du scion et des racines des arbres de pépinière. Résultats et discussion. Quel que soit le traitement, le développement du porte-greffe Rangpur a été le même jusqu'au greffage. Les plus grands volumes de container ont induit un développement végétatif plus rapide et plus vigoureux des orangers Pera greffés sur limettiers Rangpur. Finalement, des containers de 5,0 L seraient techniquement et économiquement conseillés pour la production des arbres conteneurisés de pépinière d'agrumes.

Brésil / Citrus sinensis / Citrus limonia / multiplication des plantes / pépinière / plantation en container / croissance / mesure 


\section{Introduction}

The Certified Citrus Nursery Tree Program of the State of São Paulo, Brazil, was established in order to improve the quality of citrus nursery trees commercialized in the State. This system includes the use of screened or closed environments, where the nursery trees must be grown in containers with no soil-derived substrate, water free of pathogens, and indexed budwood for viruses and Citrus Variegated Chlorosis (CVC) [1, 2]. Consequently, the production of certified citrus nursery trees becomes technically and economically viable when the nursery trees are managed in containers properly developed to be used with specific substrates.

Regarding the production of containerized citrus nursery trees, several advantages can be pointed out, such as greater control over pathogens, less time to produce nursery trees, higher root volume, higher seedling survival after transplanting, higher nutritional control and higher production of nursery trees per unit of area [3]. The disadvantages are production of smaller nursery trees, that need more care during the first year after planting, higher initial costs due to control of environmental conditions in the nursery and the risk of having to transplant nursery trees to larger containers in the case of commercialization delay $[4,5]$.

Plant density is very important for the production of nursery trees in greenhouses or even in field nurseries [6]. Aeration, light and heat distribution will certainly affect the development of plants, since there is no competition for water or nutrients. The container volume is directly related to the density of the nursery trees in the greenhouse. Cleopatra mandarin (Citrus reshni Hort. ex Tanaka) seedlings showed a better performance cultivated at $0.4 \mathrm{~m} \times 0.6 \mathrm{~m}$, while seedlings of sour orange (Citrus aurantium L.) and Swingle citrumelo [Poncirus trifoliata (L.) Raf. $\times$ Citrus paradisi Macfad.] rootstocks reached optimum growth in the field with 0.3-m spacing between double lines [7]. It was also observed that spacing did not significantly alter macronutrient leaf concentrations, but the opposite occurred with micronutrient leaf concentrations.
The volume of the substrate also seems to influence the final development of containerized citrus nursery trees, hence the necessity to test different volumes of commercial containers [8]. Therefore, it is necessary to establish research that determines if differences in development among nursery trees produced in different volume containers are exclusively attributed to physical space limitation and nutrient availability, or if the differences are mainly associated with competition for light and temperature effects. The current work attempted to evaluate the influence of different volumes of substrate and container dimensions on the development of containerized citrus nursery trees.

\section{Materials and methods}

The experiment was carried out in a commercial greenhouse that produces certified citrus nursery trees in Conchal, São Paulo State, Brazil. The geographical location is $22^{\circ} 38^{\prime \prime}$ South latitude, $47^{\circ} 35^{\prime}$ "West longitude, $590 \mathrm{~m}$ above sea level. The climate is Cwa, i.e., humid tropical with a dry winter and rainy summer [9], with an average daily temperature of $21.1^{\circ} \mathrm{C}$, annual rainfall of $1300 \mathrm{~mm}$, relative humidity of $75 \%$ and average monthly solar radiation of $201.5 \mathrm{~h}$.

The trial was developed from August to May, during the summer season. Pera sweet orange [Citrus sinensis (L.) Osbeck] was chosen as the scion variety to be studied in this experiment. Rangpur lime (Citrus limonia Osbeck) was chosen as rootstock, because it is the predominant variety in São Paulo citrus groves. Evaluation started 3.5 months after sowing, when rootstocks were transferred from seedling trays to plastic containers, and ended 8.5 months later with the commercialization of the nursery trees. The following container volumes were evaluated: $(3.0,3.8,4.5,4.6,5.0$ and 5.8) L, with the dimensions (width $\times$ height) of $(20 \times 32$, $20 \times 35,22 \times 32,22.5 \times 35,25 \times 32$ and $25 \times$ $35) \mathrm{cm}$. Another $5.0-\mathrm{L}$ container studied had the dimensions of $20 \mathrm{~cm} \times 40 \mathrm{~cm}$.

A commercial Pinus bark was used as substrate (Rendmax ${ }^{\mathrm{TM}}$ Citrus). The controlled-release fertilizer (Osmocote ${ }^{\mathrm{TM}}$ ) used was 22-04-08 + micronutrients given in the following amounts: $22 \% \mathrm{~N}, 4 \% \mathrm{P}, 8 \% \mathrm{~K}, 1 \% \mathrm{Mg}$, 
$3 \% \mathrm{~S}, 0.02 \% \mathrm{~B}, 0.05 \% \mathrm{Cu}, 1 \% \mathrm{Fe}, 0.1 \% \mathrm{Mn}$, $0.001 \%$ Mo and $0.05 \%$ Zn. For each cubic meter of substrate, $2.8 \mathrm{~kg} \cdot \mathrm{m}^{-3}$ of fertilizer was applied. Irrigation varied from (80 to 120) $\mathrm{mL} \cdot \mathrm{day}^{-1}$ for each plant, using a drip irrigation system and according to environmental conditions and substrate water saturation.

Rootstock biometric data collected before budding (3 months after sowing) consisted of the following parameters: shoot height, stem diameter measured $12 \mathrm{~cm}$ above substrate, leaf area and bud take percentage. Final shoot height, stem diameter, leaf area and scion and root dry matter were evaluated 5 months after budding. Scion and root dry matter were obtained after $72 \mathrm{~h}$ at $64{ }^{\circ} \mathrm{C}$. Leaf area was measured with an electronic planimeter (Li-Cor 3100). The experiment was conducted in randomized blocks with seven treatments in three blocks. The plot was made up of twelve containers with one plant each, in a total of 252 plants. Data collected was compared by regression analysis.

\section{Results and discussion}

The vegetative growth of Rangpur lime rootstock was not affected by substrate volume from transplant until budding (data not shown). This probably occurred because, during rootstock production, there were no physical or nutritional limitations in any of the container volumes. This behavior changed after budding, affecting mainly shoot growth during the last 4 months. This response might be a consequence of higher controlled-release fertilizer availability due to higher container volume [10].

The highest vegetative development of nursery trees after budding was directly proportional to the container volume, for all the parameters analyzed (figures 1-4). Other authors working with different substrate volumes, similar to the ones used in this experiment, also observed similar behavior in citrus nursery trees [8]. A higher volume container indicates a higher volume of substrate with more physical space, nutrient and water availability for the plants. This leads to greater vegetative development and dry matter accumulation after longer peri-

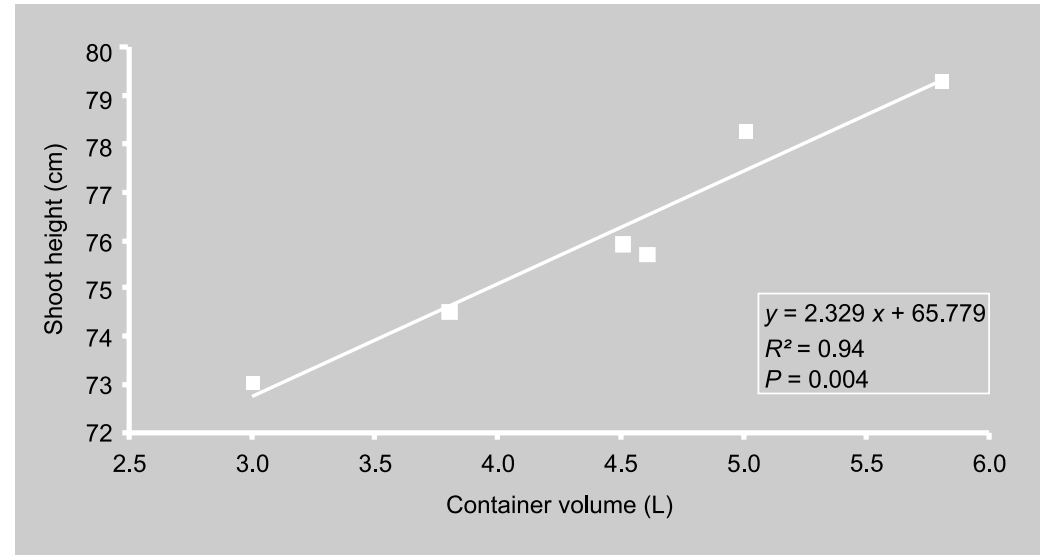

\section{Figure 1.}

Shoot height of 1-year-old Pera sweet orange nursery trees budded on Rangpur lime due to container volume, 5 months after budding ( $n=36$, Conchal-SP, Brazil, 2000).

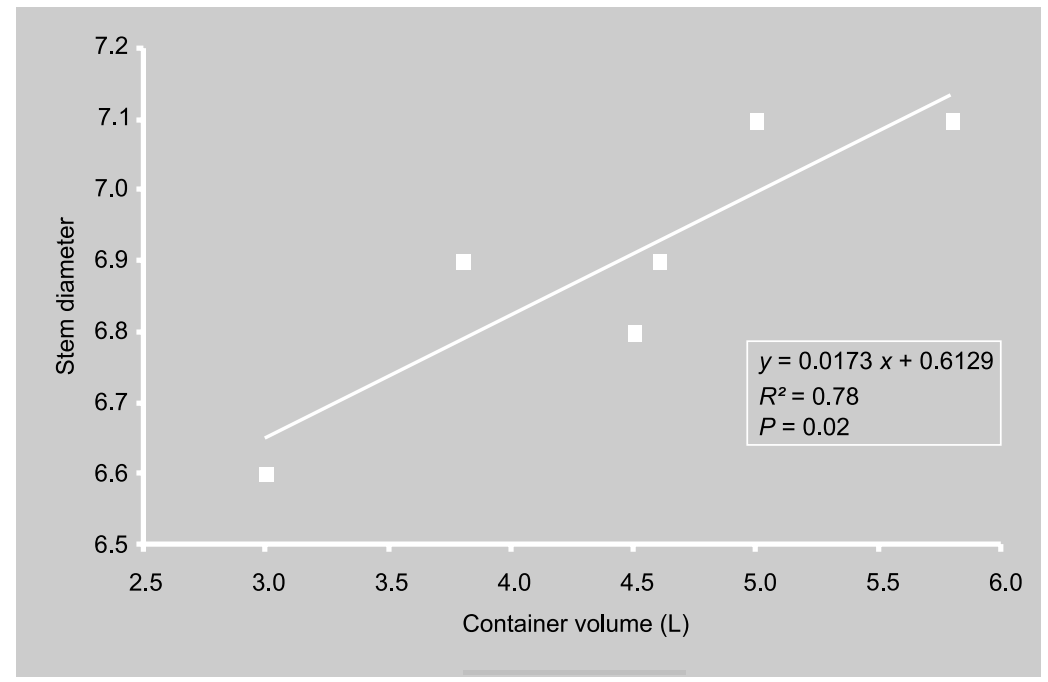

\section{Figure 2.}

Stem diameter of 1 -year-old Pera sweet orange nursery trees budded on Rangpur lime due to container volume, 5 months after budding $(n=36$, Conchal-SP, Brazil, 2000).

ods of time. However, there were no differences regarding leaf mineral composition of the scion [8], which was satisfactory according to the reference values proposed for this cultivar [11].

Irrigation was another factor to be considered. Independently of container volume, the same amount of water was applied in all treatments every time plants required irrigation. Irrigation volume varied according 


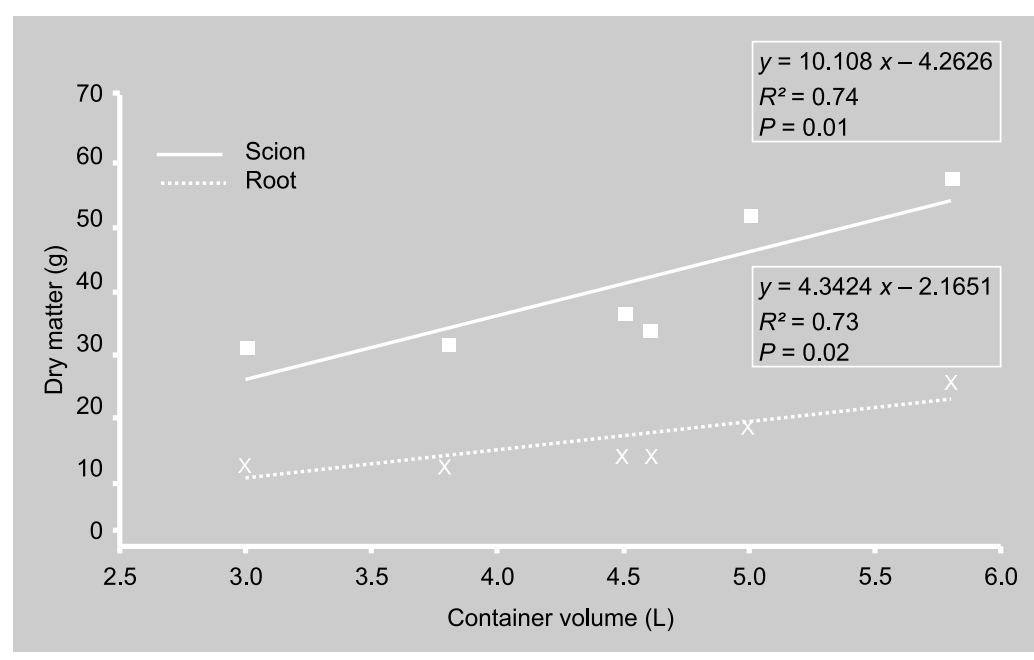

Figure 3.

Scion and root dry matter of 1-year-old Pera sweet orange nursery trees budded on Rangpur lime due to container volume, 5 months after budding $(n=36$, Conchal-SP, Brazil, 2000).

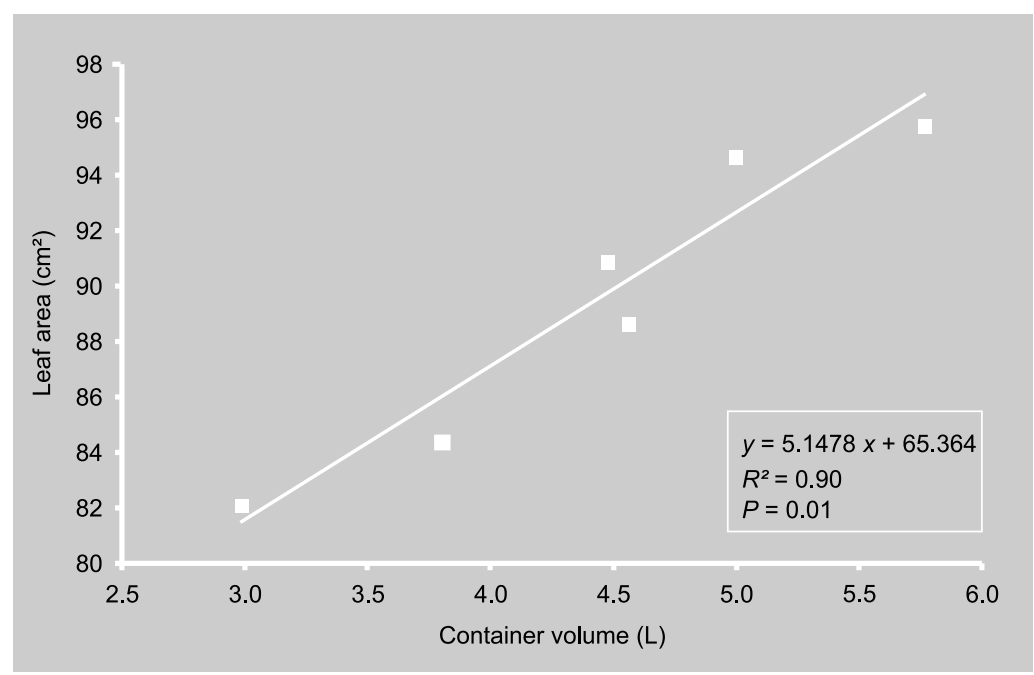

Figure 4.

Leaf area of 1-year-old Pera sweet orange nursery trees budded on Rangpur lime due to container volume, 5 months after budding ( $n=36$, Conchal-SP, Brazil, 2000).

to daily temperature. On sunny days, a volume of $120 \mathrm{~mL}$ was applied for each plant, while on cloudy days this volume was reduced to $80 \mathrm{~mL}$. Therefore, smaller containers obtained a higher grade of substrate saturation, leading to physical disorders such as lower substrate aeration, which could damage the root system. This could explain the lower development of nursery trees grown in these containers. Moreover, these conditions may promote the appearance of diseases such as foot rot Phytophthora spp. [1].

In this experiment, plant density due to container arrangement was not directly evaluated. Lower container volume allows a higher plant density in the greenhouse. There is the possibility of producing a larger number of nursery trees by using lower volumes of substrates. This would reduce substrate purchase costs and increase profits. On the other hand, smaller containers would lead to longer periods to finish nursery tree production. Five-liter containers evaluated in two dimensions $(20 \mathrm{~cm} \times 40 \mathrm{~cm}$ and $25 \mathrm{~cm} \times 32 \mathrm{~cm}$ ) did not affect nursery tree growth, although $25 \mathrm{~cm} \times 32 \mathrm{~cm}$ containers led to wider plant spacing in the greenhouse.

Five months after budding, 36\% of plants cultivated in $5.8-\mathrm{L}$ containers $(25 \mathrm{~cm} \times$ $35 \mathrm{~cm}$ ) did not reach satisfactory development for commercialization, according to the nurseryman's standards. These plants presented problems, such as short and not erect shoots, thin stems (under the average) or dormant buds. On the other hand, 64\% of plants cultivated in $3.0-\mathrm{L}$ containers $(20 \mathrm{~cm} \times 32 \mathrm{~cm})$ did not reach satisfactory development for commercialization at the same moment. Therefore, smaller container volumes lead to slower plant growth rate and therefore longer periods of time would be required for adequate vegetative development. The higher costs in this alternative system would probably suppress profits gained by greater production densities. Moreover, root damage could appear in nursery trees produced in greater densities due to the use of smaller containers; thus negative consequences could be expected on plant setting and development in the field.

\section{Conclusions}

The container volume range used in this experiment did not affect the development of Rangpur lime rootstocks until budding, 6 months after sowing.

Larger container volumes induced faster and more vigorous vegetative growth of Pera 
sweet orange nursery trees budded on Rangpur lime rootstock, using controlled-release fertilizer proportionally incorporated into the substrate.

Five-liter containers are recommended for the commercial production of well-developed Pera sweet orange nursery trees budded on Rangpur lime.

\section{References}

[1] Panzani C.R., Prates H.S., Greve A., Sistema de produção de muda certificada de citros no Estado de São Paulo, Laranja 15 (1994) 175-199.

[2] Carvalho S.A., Regulamentação atual da Agência de Defesa Agropecuária para produção, estocagem, comércio, transporte e plantio de mudas cítricas no Estado de São Paulo, Laranja 24 (2003) 199-239.

[3] Platt R.G., Opitz K.W., Propagation of Citrus, in: Reuther W. (Ed.), The Citrus Industry, Univ. Calif., Riverside, USA, 1973.

[4] Gomes M.P., Mudas em containers. Uma ótima opção, Rev. Cutrale 1 (1989) 6.
[5] Gouin F.R., Plastic planter bags, advantages and disadvantages, Nurs. Bus. 24 (1979) 63-64.

[6] Oseni T.O., Fawusi M.O.A., Performance of citrus scions on 'Cleopatra' mandarin at different nursery spacing and plant arrangements, Tropic. Agric. 69 (1992) 207-210.

[7] Oseni T.O., Fawusi M.O.A., Influence of nursery spacing and plant arrangement on the growth and leaf nutrient content on three citrus rootstocks seedlings, Trop. Agric. 64 (1987) 41-45.

[8] Rezende L. de P., Amaral A.M. do, Carvalho S.A. de, Souza M., Volume de substrato e superfosfato simples na formação do limoeiro "cravo" em vasos. I. Efeitos no crescimento vegetativo, Laranja 16 (1995) 165-177.

[9] Köppen W., Climatológia: con un estudio de los climas da tierra, fondo de cultura económica, Mexico, 1948, 478 p.

[10] Khalaf H.A., Koo R.C.J., The use of controlled release nitrogen on container grown citrus seedlings, Citrus Veg. Mag. 46 (1983) 10.

[11] Hanlon E.A., Obreza T.A., Alva A.K., Tissue and soil analysis, in: Tucker D.P.H., Alva A.K., Jackson L.K., Wheaton T.A. (Eds.), Nutrition of Florida citrus trees, Univ. Fla., Gainesville, USA, 1995.

\section{Crecimiento vegetativo de plantones cítricos debido al volumen de recipiente.}

Resumen - Introducción. La determinación de un volumen de recipiente adecuado que combine el uso racional de substratos con la maximización del crecimiento vegetativo es muy importante para la optimización de la producción de plantones cítricos. Esta investigación evaluó la influencia de diferentes volúmenes de recipientes en el crecimiento vegetativo de plantones cítricos. Materiales y Métodos. Plantones de naranja dulce Pera [Citrus sinensis (L.) Osbeck] injertados sobre Lima Rangpur (Citrus limonia, Osbeck) fueron producidos en seis diferentes volúmenes de recipientes $(3.0,3.8,4.5,4.6,5.0$ y 5.8) $\mathrm{L}$, con las siguientes dimensiones: $(20 \times$ $32,20 \times 35,22 \times 32,22.5 \times 35,25 \times 32$ y $25 \times 35) \mathrm{cm}$. Se utilizó también otro recipiente de 5,0 L con las dimensiones de $20 \mathrm{~cm} \times 40 \mathrm{~cm}$. Fue empleado un substrato comercial compuesto de cáscara de pino y fertilizante de liberación lenta. Las evaluaciones comenzaron después que los patrones fueron transferidos de las bandejas a los recipientes plásticos, 3,5 meses después de la siembra, y terminaron cuando los plantones alcanzaron un año de edad. Los datos biométricos que se colectaron fueron los siguientes: altura, diámetro y área foliar de patrones y plantones injertados, porcentaje de prendimiento del injerto, materia seca de raíces y parte aérea de los plantones y análisis foliar. Resultados y discusiones. El desarrollo de la lima Rangpur no fue afectada por ninguno de los tratamientos hasta la injerta. Los mayores volúmenes de recipientes inducirán crecimientos vegetativos mas rápidos y vigorosos en los plantones de naranja dulce Pera injertados sobre limas Rangpur. El recipiente con capacidad de 5,0 L puede ser indicado como una opción técnica y económica para la producción de plantones cítricos en recipientes.

Brasil / Citrus sinensis / Citrus limonia / propagación de plantas / viveros / plantación en contenedor / crecimiento / medicon 